\title{
A noção de verdade na fenomenologia de Husserl: entre correspondência e coerência
}

\section{The notion of truth in Husserl's phenomenology: between correspondence and coherence}

DOI: http://dx.doi.org/10.12957/ek.2015.16375

Mndo. Allan Josué Vieira

allanjvieira@hotmail.com

Universidade Federal de Santa Catarina

O presente artigo tem por objetivo explorar, em seus traços centrais, a teoria husserliana da verdade, sobretudo como ela se encontra exposta na Sexta Investigação Lógica. Neste texto, Husserl define a verdade como uma correspondência entre atos significativos e intuitivos, reestruturando a tradicional concepção da adaequatio rei et intellectus. Essa versão husserliana da adaequatio, entretanto, traz consigo algumas questões, entre as quais se procura abordar a de uma espécie de coerentismo que fundamentaria essa relação de correspondência entre os atos, tal como explicitada por Soffer (1991). As discussões buscam, então, compreender os problemas aí envolvidos, sobretudo a relação correspondência/ coerência, trazendo à cena as particularidades desta problemática sob a perspectiva maior das mudanças do pensamento de Husserl na passagem do período das Investigações lógicas para a fase transcendental de sua fenomenologia.

PALAVRAS-ChAVE verdade . evidência. fenomenologia. Husserl.

This article aims to explore, in its core features, Husserl's theory of truth, particularly as it is exposed in the Sixth Logical Investigation. In this text, Husserl defines truth as a correspondence between significative and intuitive acts, reworking the traditional concept of adaequatio rei et intellectus. Husserl's version of adaequatio, however, brings with it some questions, among which we want to address a question of a kind of coherentism that would ground this correspondence relationship between acts, as explained by Soffer (1991). Then, these discussions want to understand the problems involved therein, particularly regarding correspondence / coherence, bringing into play the particularities of this issue in the broader perspective of the changes of the Husserl's thought from the period of the Logical Investigations to the transcendental stage of his phenomenology.

KEYWORDS truth . evidence . phenomenology . Husserl. 


\section{Introdução}

O conceito de verdade deixa atestar sua importância para as pretensões da fenomenologia husserliana nas páginas de algumas das obras capitais que a estabeleceram como uma das mais influentes vertentes da filosofia do século XX. Por exemplo, atente-se para os primeiros parágrafos dos Prolegômenos à lógica pura, texto que põe em movimento a obra inaugural da fenomenologia, as Investigações lógicas" ${ }^{1}$ que o próprio Husserl considerava como uma "obra de ruptura [...] não um fim, mas um começo” (HUSSERL, 2005, p. 19): nele já é enunciada a interdependência das noções de conhecimento, ciência e verdade, e a referência destas à realidade, isto é, ao que, efetivamente, é o caso (HUSSERL, 2005, p. 38). Ora, na conexão afirmada entre estes conceitos já se deixa entrever a relação entre pensamento e realidade, mediada pela linguagem. É na verdade que o pensamento que pretende 'dizer' o mundo encontra sua meta. ${ }^{2} \mathrm{O}$ que se tem, então, é, talvez, um dos problemas maiores com os quais a filosofia ocidental tem se ocupado por mais de dois milênios.

Em estreita ligação com isso, o conceito de verdade desempenha papel relevante na crítica que Husserl faz, nos Prolegômenos, ao psicologismo e ao relativismo dele decorrente. E isso sobre bases que colocam em causa a própria possibilidade de um mundo para nós: pois a relativização da verdade conduz à relatividade da existência de um mundo, visto que este é "a unidade objetiva completa que corresponde ao sistema ideal de todas as verdades de fato, e dele é inseparável" (HUSSERL, 2005, p. 136). Além disso, a verdade, para Husserl, pertence ao conjunto de conceitos dos quais se originam os princípios da lógica enquanto leis ideais $(2005$, p. 137, 151). Também a 'elucidação fenomenológica do conhecimento' proposta na Sexta Investigação Lógica conduz à abordagem da noção de verdade que se tornará canônica para Husserl. Ou seja, não só a verdade é tema ineludível para a filosofia (mesmo que implicitamente, pois todo esforço de um autêntico fazer filosófico parece trazer em si a pretensão de ser verdadeiro), como se mostra um conceito fundamental para a fenomenologia.

O presente texto tem como objetivo expor, em suas linhas centrais, a definição de verdade elaborada por Husserl, especialmente no período das $L U$, atentando para os elementos já presentes nos Prolegômenos e desenvolvidos em maior detalhe na $L U V I$. O foco de nossa atenção será a maneira como

1Doravante, $L U$, com um numeral romano indicando a investigação citada (ex. $L U V I=$ Sexta Investigação Lógica).

2 Lynch (2011, p. 5, tradução nossa) afirma que uma verdade 'familiar' sobre a verdade é que ela "é o objetivo, ou o fim, de uma investigação", e esta é definida como qualquer processo de fazer e responder questões. 
Husserl propõe uma nova versão da verdade como adaequatio rei et intellectus, observando seus pressupostos e alguns dos desdobramentos daí decorrentes.

A exposição, então, dar-se-á da seguinte maneira: num primeiro momento, serão explicitados conceitos relevantes para a compreensão da teoria husserliana da verdade (tais como os de preenchimento intuitivo, síntese de identificação ou recobrimento, evidência etc.). Em seguida, certos corolários decorrentes das definições oferecidas por Husserl serão citados, especialmente os que se referem à ideia da verdade como correspondência no esquema conceitual circunscrito pela $L U V I$. Especificamente, será apresentada a leitura de Soffer (1991), para quem determinados caracteres da teoria husserliana sugerem uma base coerentista para a noção correspondencial da verdade. Por fim, essa interpretação será debatida à luz daquilo que é apresentado nas $L U$, assim como a partir de outros textos, especialmente de Ideias para uma fenomenologia pura ${ }^{3}$ e das Meditações cartesianas. ${ }^{4}$

\section{A teoria husserliana da verdade como modificação da noção correspondencial tradicional}

A ideia central para a compreensão da teoria husserliana da verdade é, sem dúvida, como bem o afirma Bernet (1988), a de preenchimento intuitivo. A fim de determinar o alcance e a significância de conceitos como conhecimento, evidência e verdade na fenomenologia de Husserl, o exame das sínteses de preenchimento desempenha papel fundamental (BERNET, 1988, p. 34). Desse modo, uma série de considerações é necessária, a fim de precisar melhor alguns pontos centrais relativos à nossa temática.

\subsection{Intenções vazias e preenchidas: a síntese de preenchimento}

A partir de um dos tópicos capitais da fenomenologia, a saber, o da intencionalidade da consciência, que segue o bem conhecido mote de que 'toda consciência é consciência de algo', pode-se distinguir dois modos de acordo com os quais um objeto é visado: em intenções vazias ou 'cheias' ('preenchidas', na linguagem husserliana). De acordo com Sokolowski (1973, p. 19), cada espécie de objeto apresenta uma maneira particular de ser visado em sua

3 Doravante, abreviada como Ideias I.

4Doravante, $C M$. 
ausência (intenções vazias) ou de ser dado intuitivamente (em intenções preenchidas). São relevantes para a presente investigação os chamados atos ou intenções objetivantes, isto é, que se referem de alguma forma a um objeto. Esta classe de vivências, por sua vez, divide-se, primariamente, entre significativas $^{5}$ e intuitivas (signitiven und intuitiven Intentionen) ${ }^{6}$ (HUSSERL, 1985, $\mathrm{p}$. 44). As intenções significativas se manifestam em expressões linguísticas, e são portadoras de um sentido ideal (que não se confunde ou reduz a nenhum elemento contido nas ocorrências fáticas do ato de exprimir), por meio do qual são visados objetos (ou, num sentido mais amplo, e numa linguagem tipicamente husserliana, 'objetidades') (HUSSERL, 2012, p. 34-47). Os atos que remetem significativamente a uma dada objetidade são sempre vazios (HUSSERL, 1985, p. 60), ou seja, o modo como representam seus objetos não contém nada que dê algo destes 'em carne e osso'. Por outro lado, os atos intuitivos têm o caráter de trazer algo que falta aos atos significativos, aquilo que Husserl chama de 'plenitude' da representação: um conteúdo que não está presente nas intenções puramente significativas, mas que, no ato intuitivo, apresenta algo do próprio objeto. Segundo Husserl (1985, p. 61, grifo do autor, tradução modificada), "a plenitude [Fülle $]^{7}$ da representação é o conjunto daquelas determinações pertencentes à própria representação, por meio das quais ela presentifica por analogia seu objeto, ou o apreende como dado ele próprio”. A intuição, portanto, é uma vivência na qual se tem 'diante de si' o que, num ato signitivo, era visado meramente de maneira vazia, na ausência do objeto. ${ }^{8}$ Nas Investigações lógicas, a doação intuitiva de algo está associada diretamente à apreensão de conteúdos pré-intencionais, que são, por meio de um modo de apreensão que lhes é próprio, referidos ao objeto intencional (BERNET, 1988, p. 34). Esses conteúdos são o que Husserl (1985, p. 52, grifo do autor) chama de "conteúdos apresentantes" ou, ainda, "conteúdos representantes-apreendidos intui-

5 Nas $L U$, especialmente na Sexta Investigação, Husserl também usa a expressão "signitivas", sem atentar para uma distinção mais precisa entre ambos os termos. Aqui, serão usados como sinônimos.

6Cf. HUSSERL, 1984, p. 586.

7Cf. HUSSERL, 1984, p. 607. A tradução da LU VI para o português utiliza o termo 'recheio' para verter o alemão 'Fülle'. Preferimos seguir a indicação da nova tradução das Investigações, onde se lê 'plenitude'. Cf. HUSSERL, 2012, p. 446.

8 Para facilitar a compreensão do que Husserl pretende expressar com 'intuição', podem ser úteis os exemplos utilizados por Moran (2012, p. 172): o termo alemão Anschauung é formado a partir do verbo schauen, que significa 'ver', 'olhar para', assim como a expressão latina intuitus deriva do verbo intuire, 'ver'. 
tivos" ${ }^{9}$ (darstellenden, intuitiv repräsentieren Inhalten). ${ }^{10}$ Trata-se de dados de sensação, no caso das percepções externas, ou de "fantasmas sensíveis", no caso de uma afiguração imaginativa de um objeto exterior (uma "fantasia externa”) (HUSSERL, 1985, p. 62). Estes conteúdos, enquanto apreendidos, juntamente com a apreensão (Aufassung) ${ }^{11}$ que lhes corresponde, constituem o teor intuitivo de um ato (por exemplo, de uma percepção ou uma afiguração na imaginação) $)^{12}$ (HUSSERL, 1985, p. 63).

Segundo Sokolowski, a linha divisória traçada por Husserl entre atos significativos, de um lado, e intuitivos, de outro, demonstra o caráter particular de cada classe de ato, bem como estabelece sua diferença essencial, qual seja, a oposição entre a referência 'vazia' a um objeto e a presença deste (especialmente no caso da percepção):

A distinção crucial é entre visar o objeto com base em signos ou expressões, que são um visar vazio, e visá-lo diretamente, seja em sua presença ou por meio de uma imagem. Essa diferença se reflete no fato de que nós dizemos "este é Napoleão", de modo a identificá-lo, seja porque nós estamos olhando para ele, seu retrato ou estátua, ou imaginando-o em nossas mentes; mas não podemos dizer isso a respeito de seu nome ou de qualquer das palavras usadas para falar sobre ele. Ele "não está lá" de maneira alguma em uma intenção

9 Cabe destacar que, para Husserl, o termo 'representação' (Vorstellung) e seus correlatos não significam o mesmo que tradicionalmente se associa às teorias modernas da representação. A representação torna-se sinônimo de um ato objetivante, ou seja, um ato por meio do qual um objeto é apresentado à consciência: uma proposição, uma lembrança, uma percepção (cf. $L U V$, $\S 37 \mathrm{ss}$ ). Não se está lidando com algo do tipo de uma cópia do objeto; é o próprio objeto que é visado por meio de determinados conteúdos e pelos atos correspondentes. Assim, os conteúdos representantes-apreendidos intuitivos não são dados que fornecem um substituto para o objeto; eles são conteúdos que, de diferentes modos, apresentam o objeto ao sujeito.

10Cf. HUSSERL, 1984, p. 609.

11 Cf. HUSSERL, 1984, p. 610.

$12 \mathrm{O}$ termo 'intuição', tal como exposto nas $L U$, não diz respeito somente às percepções diretas dos objetos; também se associa à representação na imaginação. A representação intuitiva traz algo do próprio objeto à presença, seja numa imagem figurada, ou no contato com o próprio objeto (HUSSERL, 1985, p. 61). Claro está, existem diferenças no nível da 'plenitude' e do preenchimento, de acordo com o tipo de intenção envolvida (perceptiva ou imaginativa). Nesse sentido, Soffer (1991, p. 77) assinala que mesmo figuras, imagens ou a memória podem trazer preenchimento a uma intenção signitiva em alguma medida. No entanto, a forma mais perfeita ou completa de preenchimento seria a consciência perceptiva, uma vez que, aí, o objeto se dá ele mesmo. A afiguração imaginativa pode fornecer algo do objeto, mas não o oferece diretamente; para tanto, faz-se necessária a percepção. Cf. LU VI, $\S \S 14,21-22,37$. 
signitiva, embora seja apresentado ou representado nas outras ${ }^{13}$ (SOKOLOWSKI, 1974, p. 25, tradução nossa).

Em resumo, nas palavras de Husserl, a diferenciação essencial entre intenções signitivas e intuitivas se dá do seguinte modo: “A intenção signitiva simplesmente indica o objeto, a intuitiva o representa no sentido estrito da palavra; ela traz consigo algo da plenitude do próprio objeto" (HUSSERL, 1985, p. 60-61). ${ }^{14}$ O ponto chave para a explicitação da concepção husserliana da verdade reside na relação possível entre intenções vazias e cheias (ou seja, signitivas e intuitivas). Esta relação é a "consciência de preenchimento" (Erfüllungsbewußtsein) $)^{15}$ ou "síntese identificante" (identifizierende Synthesis) ${ }^{16}$ (HUSSERL, 1985, p. 27 , p. 29), isto é, a ligação entre aquilo que é visado e o estado de coisas que se dá em si mesmo, intuitivamente. Esse preenchimento pode se dar de dois modos: estático ou dinâmico. Numa síntese estática, tem-se um ato signitivo fundado numa intuição, estabelecendo uma ligação com seu objeto por meio desta. Tome-se como exemplo o caso apresentado por Husserl: estou diante do meu tinteiro, ao mesmo tempo em que falo a seu respeito (HUSSERL, 1985, p. 24). Obviamente, não se trata de uma relação entre as palavras proferidas e o objeto físico (elas não estão 'dentro' das coisas ou fisicamente ligadas a elas). A conexão se dá entre as vivências (significativa, por um lado, e intuitiva, por outro). O que serve como médium para essa relação é um ato de conhecimento, ou de classificação, nesse caso da identificação estática: o objeto percebido é conhecido ${ }^{17}$ como o meu tinteiro, e a intenção significativa se liga a essa vivên-

13 "The crucial distinction is between meaning the object on the basis of signs or expressions, which is empty intending, and directly meaning it either in its own presence or in its image. This difference is reflected in the fact that we say, "That is Napoleon", in an identifying way, whether we are looking at him, his portrait or statue, or imagining him in our mind's eye; but we could not say this about his name or any of the words used to talk about him. He "isn't there" in any way to a signitive intention, although he is presented or represented in the others".

14 Sokolowski (1974, p. 18-19) fornece uma série de exemplos ilustrativos da relação entre visadas vazias e cheias. Pode-se visar algo significativamente falando a seu respeito, como numa conversa sobre um lugar que se está prestes a visitar (por exemplo, um lago). Visá-lo intuitivamente poderia ser o ato de vê-lo diretamente, ouvir o barulho das águas, nadar no lago. Obviamente, um ato de imaginar o lago seria algo com 'plenitude' em relação ao mero falar a seu respeito; contudo, esse caso ainda seria um ato carente de plenitude em relação à intuição perceptiva do lago. Percebe-se, assim, que a relação entre os diferentes tipos de visada de uma objetidade é mais complexa do que pode parecer à primeira vista.

15Cf. HUSSERL, 1984, p. 566.

16Cf. HUSSERL, 1984, p. 563.

$17 \mathrm{Na}$ tradução para o inglês, Findlay prefere verter por recognition o termo utilizado por Husserl, das Erkennen. Sokolowski (1974, p. 28-29) também se vale do termo recognition. Com efeito, a ideia de reconhecimento parece concordar melhor com o contexto da discussão da 
cia intuitiva na qual o objeto se dá em si mesmo "como se fora sua vestimenta" (HUSSERL, 1985, p. 24-25). De outra parte, um ato de preenchimento dinâmico consiste em um desdobramento temporal da experiência: primeiro, há a intenção signitiva vazia, que se refere ao seu objeto. Em seguida, vem juntar-se a essa intenção uma intuição na qual o objeto se dá. Há, aí, uma consciência de preenchimento: "Experimentamos como, na intuição, é presentificada intuitivamente a mesma objetidade que, no ato simbólico, era 'apenas pensada'; e também que ela se torna intuitiva com aquelas mesmas determinações com as quais foi, de início, apenas pensada (apenas significada)" (HUSSERL, 1985, p. 29-30). A característica decisiva nessa relação, segundo Soffer (1991, p. 76), é que, embora pertencentes a duas classes muito diferentes de atos, as intenções signitivas e intuitivas podem visar o mesmo objeto, e da mesma forma, isto é, elas podem possuir o mesmo sentido. Desse modo, segue-se que:

preenchimento é o que nós experienciamos quando, primeiro, tomamos em consideração um juízo, meramente de forma signitiva; então, subsequentemente, experimentamos o mesmo conteúdo de sentido como dado na intuição e, além disso, reconhecemos os dois sentidos como sendo o mesmo [...] A característica comum a todos os preenchimentos é que o objeto, de alguma maneira, é mostrado, e não simplesmente denotado por um signo $^{18}$ (SOFFER, 1991, p. 76, tradução nossa).

Esse recobrimento entre os diferentes modos de visar o objeto (que, justamente, partilham de um mesmo sentido) delimita a relação de conhecimento, fenomenologicamente descrita. Analisando a relação de unidade dinâmica, Husserl a faz refletir sobre a estática, e clarifica o que é próprio da vivência de conhecimento, explicitando seus momentos essenciais:

Em primeiro lugar, aqui a intenção de significação é dada, e de per si; só depois vem juntar-se a intuição

síntese de identificação estática. No entanto, optou-se aqui por manter a terminologia adotada na tradução para o português

18 "fulfillment is what we experience when first we entertain a judgment merely signitively, then subsequently experience the same meaning-content as given in intuition, and further, recognize the two contents to be the same [...] The general feature shared by all fulfillments is that the object is in some way shown, and not simply denoted by a sign." 
correspondente. Ao mesmo tempo, produz-se a unidade fenomenológica que se manifesta então como consciência de preenchimento. Falando em conhecimento do objeto e em preenchimento da intenção de significação, exprimimos, portanto, o mesmo estado de coisas, só que de diferentes pontos de vista. No primeiro caso, o ponto de vista é o do objeto visado, ao passo que, no último, tomamos por pontos de referência somente os atos, dos dois lados [...] Assim, falando em preenchimento estamos dando à essência fenomenológica da relação de conhecimento uma expressão que a caracteriza melhor (HUSSERL, 1985, p. 30).

Desse modo, percebe-se que conhecer equivale à consciência da concordância entre aquilo que era visado de forma somente significativa (numa visada vazia) e a intuição dada, e tal como é dada. ${ }^{19} \mathrm{O}$ conhecimento, como resultado do recobrimento entre os atos, é essa própria unidade de recobrimento (HUSSERL, 1985, p. 33). Agora, importa destacar que a consciência do preenchimento é uma vivência em si mesma, assim como a vivência de significação e a intuitiva. Ela é um ato, distinto dos outros dois. ${ }^{20} \mathrm{E}$, como tal, possui uma objetidade própria da qual ela é consciência. Há aqui uma vivência da identidade, um ato de identificação. E essa identidade é o objetal ao qual esse modo de consciência se volta. Assim, o objeto dessa vivência é conhecido, e não simplesmente percebido ou representado na imaginação, pois é a objetidade que corresponde à consciência da identidade entre intenção de significação e intuição: "O caráter do conhecido é dado ao objeto que aparece na intuição, quando estamos voltados primariamente para este último, pela circunstância de que a intenção de significação se une ao intuir, à maneira do preenchimento" (HUSSERL, 1985, p. 31). A identidade, além disso, não é algo introduzido entre os atos significativo e intuitivo por meio de uma reflexão; é uma vivência "não expressa e não concebida" (HUSSERL, 1985, p. 31), que está presente na relação desde seu início.

19Note-se que o conhecer e seu correlato, a síntese de preenchimento, não dizem respeito somente à unidade dinâmica, mas também à estática. A diferença é que, na dinâmica, ficam mais claros os diferentes componentes da vivência fenomenológica da identificação. A unidade de identidade entre o visado signitivamente e o intuído se estabelece nos dois modos de síntese. Husserl deixa esse ponto claro no final do $\S 8$ da $L U V I$.

$20 \mathrm{Na} L U I$, Husserl já assinala que o ato que preenche a significação (a intuição) não deve ser confundido com a vivência completa da identidade entre os dois atos, a qual perfaz a unidade de conhecimento ou de preenchimento em sentido estrito (HUSSERL, 2012, p. 32). 
A noção de verdade na fenomenologia de Husserl: entre correspondência e coerência
Mndo. Allan Josué Vieira

[UFSC]

A necessidade de se especificar essa complicada operação intencional da consciência, envolvendo três atos distintos, impõe-se a Husserl, segundo Sokolowski, a fim de que se possa fazer justiça à relação de conhecimento, distinguindo-a da simples percepção sensível ou afiguração imaginativa dos objetos:

Por que todo esse mecanismo? Estas partes devem ser distinguidas porque reconhecer ou conhecer algo é [um ato] complexo. Não é simplesmente ter uma impressão do objeto; ter apenas o objeto presente, sem a manifestação de sua identidade, não é reconhecer ou conhecer o objeto. Não é ter uma percepção consciente. Reconhecer a identidade do objeto é ter o objeto conscientemente, o modo como um ser humano tem objetos - com a possibilidade de expressar o que lhe é presente. Esse tipo de presença torna possível ser verdadeiro, falhar em ser verdadeiro, e ser enganado ${ }^{21}$ (SOKOLOWSI, 1974 , p. 29 , tradução nossa). ${ }^{22}$

Essa síntese de preenchimento, enquanto ato por si mesma, encontra um de seus pontos chave no fato de que os atos que são aí ligados apresentam um valor cognitivo diferente. É isso que torna o preenchimento epistemicamente relevante (BERNET, 1988, p. 34). A intenção intuitiva traz algo como uma visualização do objeto, sua plenitude coloca o sujeito frente à objetidade de uma maneira que na intenção significativa não era possível. De acordo com Husserl:

A síntese de preenchimento revela uma desigualdade de valor entre os membros ligados, de modo que o ato preenchedor contribui com uma prerrogativa que falta

210 'ser enganado' equivale à 'decepção': diz respeito às sínteses de distinção, em contraposição à identidade, nas quais a intuição dada entra em conflito com a intenção significativa. Ou seja, é o contrário do preenchimento: o que é dado não corresponde àquilo que era visado. Husserl esclarece as relações de decepção e conflito no $\S 11$ da $L U V I$.

22 "Why all this machinery? These parts must be distinguished because recognizing or knowing something is complex. It is not simply having an impression of the object; just to have the object present, without manifestation of its identity, is not to recognize or to know the object. It is not to have a thoughtful perception. To recognize the identity of the object is to have the object thoughtfully, the way a human being has objects - with the possibility of expressing what is present to him. This kind of presence makes it possible to be truthful, to fail to be truthful, and to be deceived" 
A noção de verdade na fenomenologia de Husserl: entre correspondência e coerência
Mndo. Allan Josué Vieira

[UFSC]

à mera intenção, a saber, ele the confere a riqueza do "próprio", aproxima-a, pelo menos mais diretamente, da própria coisa (HUSSERL, 1985, p. 53, grifo do autor).

A diferença de valor entre as intenções signitivas e intuitivas se assenta sobre os já mencionados conteúdos representantes-apreendidos intuitivos. ${ }^{23}$ Estes, juntamente com um modo próprio de apreensão que lhes é adequado (apreensão captativa para dados sensíveis, apreensão afigurativa para os dados da imaginação), constituem o teor intuitivo do ato, ou sua plenitude. O complexo que forma o que Husserl chama de essência cognitiva do ato intuitivo é composto, portanto, da matéria, da qualidade e da plenitude (ou teor intuitivo) do ato. ${ }^{24} \mathrm{~A}$ essência cognitiva se distingue da essência significacional dos atos signitivos (HUSSERL, 1985, p. 75), uma vez que esta compreende somente o correlato do sentido ideal idêntico, contido no ato de expressão como um componente seu. ${ }^{25} \mathrm{~A}$ essência cognitiva apresenta um conteúdo que não é abarcado pela essência intencional de um ato objetivante em geral, já que, além de qualidade e matéria do ato, também apresenta a plenitude, que fornece um 'plus' em relação ao ato significativo, carente de plenitude. Bernet resume bem o que está em jogo, em termos cognitivos, no processo de preenchimento:

23É necessário ter claro que mesmo os atos puramente significativos apresentam um conteúdo representante-apreendido, que, nesse caso, é signitivo, e não intuitivo. Trata-se da instância material (o som de uma frase proferida, uma inscrição numa folha de jornal) que funciona como um conteúdo que remete para além de si mesmo (ou seja, é apreendido meramente como signo). Ele não fornece nenhuma plenitude em relação ao objeto visado por meio do ato significativo (HUSSERL, 1985, p. 75). Ao lermos uma notícia a respeito da Torre Eiffel, o que se visa é, justamente, este objeto, e não a inscrição dada intuitivamente. Ou seja, o dado é apreendido signitivamente, e não intuitivamente. Todo ato objetivante tem como elemento último as chamadas 'representações apreensivas' (Repräsentationen - cf. HUSSERL, 1984, p. 624) que colocam em relação, de formas distintas (signitivamente, intuitivamente) os conteúdos que são apreendidos e a matéria do ato intencional (cf. $L U V I, \S 27)$. Sobre as distinções e relações entre matéria, ato e essência intencional, ver nota abaixo.

24 A matéria e a qualidade de um ato constituem a sua essência intencional. A primeira determina o 'como-o-quê' o objeto é visado, o modo como ele é intencionado (HUSSERL, 2012, p. 356). Por exemplo, podemos falar de uma casa marrom, olhar para essa casa marrom, lembrar dela como uma casa marrom, e assim por diante. Em todos esses atos, a matéria é a mesma: o 'ser marrom' da casa; é dessa forma que ela é visada em todos os atos. Já a qualidade é o momento do ato que estabelece seu caráter específico, como o de ser uma lembrança, uma percepção, uma imaginação, um juízo etc. Cf. $L U V, \S 20$.

25 Para tornar esse ponto claro, pode-se utilizar uma sugestão de Smith (2007, p. 113), que adota a terminologia de Peirce (embora o façamos aqui com algumas modificações): a significação ideal seria algo como um 'sentence type', enquanto sua 'instância' contida no ato significativo seria um 'sentence token'. É este último que constitui a essência significacional do ato. Na definição dada por Husserl, diz-se que "a sua essência significativa [dos atos significativos], isto é, aquilo que neles forma o correlato fenomenológico real da significação ideal, coincide com sua essência intencional" (HUSSERL, 2012, p. 360, itálico do autor, negrito nosso). 
A diferença cognitiva entre o ato preenchedor e o ato a ser preenchido, assim, a diferença entre dois atos intencionais que visam o mesmo objeto, deriva, portanto, do seu modo de representação [Repräsentation] intuitiva ou do alcance e riqueza do material sensível em ambos os atos em algum dado momento. Formalmente concebido, o processo de preenchimento é, assim, um ato complexo que traz dois atos a uma relação sintética com respeito a ambos, a identidade do seu objeto intencional, e a diferença entre as representações intuitivas desse objeto ${ }^{26}$ (BERNET, 1988, p. 34-35, grifo do autor, tradução nossa)

Por essa explicação, torna-se patente que os dois atos unidos sinteticamente na síntese de preenchimento visam o mesmo objeto, e da mesma maneira, com as mesmas determinações; mas um o intenciona de forma vazia, carente de plenitude, enquanto o outro o apresenta, em alguma medida, em 'si mesmo'.

Uma vez definidos os traços gerais da síntese de preenchimento ou de identidade entre o que é visado significativamente e o que é dado na intuição, pode-se passar à exposição da teoria husserliana da verdade e sua correlação com o conceito de evidência, tal como apresentada, sobretudo, nas $L U$.

\subsection{A correlação entre evidência e verdade}

A noção de evidência, fundamental para o conceito de verdade na fenomenologia de Husserl, depende determinantemente da distinção entre intenções vazias e preenchidas (SOFFER, 1991, p. 67). Com efeito, a síntese de preenchimento, enquanto ato que possui como correlato uma objetidade que lhe é própria, permite compreender algo que Husserl anuncia já nos Prolegômenos à lógica pura. Aí, o filósofo afirma que "a vivência da consonância entre o visado e

26 "The cognitional difference between the fulfilling act and the act to be fulfilled, hence, the difference between two intentional acts which intend the same object, thus derives from their mode of intuitive representation [Repräsentation] or from the range and richness of the sensational material apperceived in both acts at any given moment. Formally conceived, the process of fulfillment is thus a complex act which brings two acts into synthetic relation in respect to both the identity of their intentional object and the difference between their intuitive representations of this object". 
o que está presente em si mesmo, que ele visa, entre o sentido atual da asserção e o estado de coisas dado em si mesmo é a evidência, e a ideia desta consonância, a verdade" (HUSSERL, 2005, p. 197, grifo do autor). A evidência, portanto, é definida primordialmente como a vivência da síntese de recobrimento entre o que é visado (e, nos Prolegômenos, conforme a passagem citada, isso se traduz numa intenção signitiva enquanto visada carente de plenitude) e o que é dado intuitivamente, experienciado de forma direta pelo sujeito. O correlato da doação evidente do objeto é a verdade, e, conforme exposto, é uma ideia, no sentido de que não depende de condições psicológicas particulares de um indivíduo qualquer. Antes, a correlação evidência-verdade assenta na idealidade da significação da asserção (o que garante sua identidade, independentemente de atos subjetivos que a pensem ou pronunciem) e na vivência do estado de coisas que se dá em si mesmo. A verdade, desse modo, é uma ideia, pois se trata da possibilidade (e não de um mero fato contingente) da vivência de um julgar evidente. ${ }^{27}$ De acordo com Husserl, "existe evidentemente uma equivalência geral entre as proposições ' $A$ é verdadeiro' e 'é possível que alguém julgue, com evidência, que $A$ é" (HUSSERL, 2005, p. 191, grifo do autor).

Na $L U V I$, Husserl aprofunda e especifica as discussões sobre os conceitos de verdade e de evidência. Pode-se considerar que muitos dos temas tratados nos Prolegômenos encontram uma formulação mais clara neste texto. São estabelecidos nada menos que quatro sentidos para 'verdade', em correlação com o que é dito sobre o vivido da evidência. É importante salientar que Husserl, ao esclarecer o que se entende fenomenologicamente por 'evidência', está preocupado não somente com as meras possibilidades de preenchimento intuitivo, mas com as relações que, efetivamente, são capazes de fornecer esse preenchimento. Atenção especial é dada às vivências de percepção, pois é graças a estas que temos “as próprias coisas" (HUSSERL, 1985, p. 90). O que está em jogo são os atos posicionais $^{28}$, pois é em ligação com estes que se produz a evidência. Toda

27 Importa notar que, no contexto dos Prolegômenos, Husserl está buscando elementos para a refutação das teorias psicologistas da evidência e da verdade. Por isso a insistência no caráter ideal da relação entre estas vivências. Como o próprio Husserl assinala no prefácio à segunda edição das Investigações, o conceito de "verdade em si", fundado nessa idealidade da correlação, estava demasiadamente orientado para as "vérités de raison", ou seja, verdades como as das esferas da matemática e da lógica (HUSSERL, 2005, p. 22-23). Este fato também é assinalado por Soffer (1991, p. 67): a preocupação de Husserl seria garantir que um juízo portador de uma mesma significação ideal não poderia, por vezes, ser acompanhado de evidência, e em outros momentos, não.

$28 \mathrm{Na}$ LU V, $\S \S 38$ e 41, Husserl assinala para uma diferenciação qualitativa entre os atos objetivantes. Os atos posicionais trazem implicitamente um caráter de crença, de belief, de "ter-por-verdadeiro" seu objeto (HUSSERL, 2012, p. 424). Eles são, portanto, posicionais em relação à sua qualidade. Contrapõem-se a eles os atos objetivantes não-posicionais, indiferentes quanto ao ser ou não ser da objetidade visada. 
síntese de identificação entre dois atos intencionais é um ato posicional, isto é, põe como efetivamente existente o seu objeto, e da mesma forma como é visado (segundo sua matéria), pois se trata de um ato de confirmação (ou verificação), no qual a objetidade visada é dada intuitivamente, e, em última instância, dada “ela mesma" numa percepção (HUSSERL, 1985, p. 93).

De acordo com Husserl:

Falamos em evidência, no sentido lato, sempre que uma intenção posicionante [setzende Intention] (sobretudo, uma afirmação) é confirmada por uma percepção correspondente e perfeitamente adequada, mesmo que se trate de uma síntese adequada de percepções singulares conexas. É legítimo então falar em graus de evidência (HUSSERL, 1985, p. 93).

A evidência comporta graus, dado que as percepções não nos dão o objeto 'completo'; ele é sempre visado por 'perfis' ou "sombreamentos" (Abschattungen $)^{29}$ (HUSSERL, 1985, p. 90). Isso significa que "as determinações que a cada momento entram na percepção nos remetem às determinações complementares, que aparecem, elas próprias, em novas percepções possíveis" (HUSSERL, 1985, p. 35). Por exemplo, se vemos a fachada de uma casa, suas outras partes permanecem apenas 'co-visadas'; a parede de trás não está presente na experiência atual, mas pode ser dada em percepções subsequentes, de acordo com o ponto de vista adotado. Esse caráter essencial das percepções indica, então, um ideal no qual as intenções seriam plenamente preenchidas: é uma "percepção idealmente perfeita" (HUSSERL, 1985, p. 91). É em relação a esse ideal que Husserl estabelece o sentido estrito de evidência: é a meta "última e insuperável" em que o próprio objeto daria o preenchimento à intenção significativa (HUSSERL, 1985, p. 93). À evidência, então, corresponde a noção de verdade: "A própria evidência, dizíamos, é o ato daquela síntese de recobrimento, a mais perfeita de todas. Como toda identificação, ela é um ato objetivante. Seu correlato objetivo é chamado de ser no sentido da verdade ou também de verdade" (HUSSERL, 1985, p. 93, grifo do autor). ${ }^{30}$

Correlativamente à determinação da vivência da evidência, surgem quatro

29Cf. HUSSERL, 1984, p. 646. 
noções interligadas de verdade:

1) o correlato de um ato identificante, a "plena concordância entre o visado e o dado como tal" (HUSSERL, 1985, p. 94). É o polo objetal do ato de identificação, o 'o quê' ao qual esse ato se volta, o ‘objeto' que é produto do ato da evidência;

2) a relação ideal vigente na vivência da evidência, que é a ideia do recobrimento entre as essências cognitivas dos dois atos ligados (ou seja, o recobrimento entre suas matéria e qualidade, mais o acréscimo proporcionado pelo teor intuitivo do ato que traz o preenchimento), é a "ideia da adequação absoluta" (HUSSERL, 1985, p. 94). Como Husserl explica, se a definição anterior se dirigia ao correlato objetal da evidência, esta segunda noção corresponde à forma desse ato, ou seja, à essência cognitiva enquanto ideia que subjaz à relação de recobrimento das essências cognitivas dos atos significativo e intuitivo; ${ }^{31}$

3) relativamente ao ato intuitivo, o objeto aí dado é vivido como "o ser, a verdade, o verdadeiro" (HUSSERL, 1985, p. 94), pois ele é a plenitude ideal da intenção vazia, de sua essência cognitiva;

4) pelo lado da intenção significativa, a verdade é a correção da intenção (por exemplo, correção de um juízo): o visar significativo se adéqua à própria coisa.

Comentando essas definições, Soffer (1991, p. 79, grifo do autor, tradução nossa) oferece a seguinte leitura:

O sentido primário da verdade nas análises husserlianas, e aquele do qual os outros derivam, é o primeiro: a verdade como a concordância entre intenção e preenchimento. O segundo sentido não é mais que uma concepção generalizada do primeiro, o universal do qual a verdade no sentido 1 é o particular. De acordo com o terceiro sentido, um ente é um ser "verdadeiro" quan- 
A noção de verdade na fenomenologia de Husserl: entre correspondência e coerência
Mndo. Allan Josué Vieira

[UFSC]

do ele pode ser dado adequadamente na intuição, isto é, um ente para o qual a evidência adequada [Evidenz] ou a verdade no sentido 1 é idealmente possível. Finalmente, um juízo é verdadeiro quando ele é correto (richtig), no sentido de que ele se conforma ao (richtet sich nach) ente verdadeiro, a um objeto que é ou pode ser dado adequadamente [...] Por causa da primazia do primeiro sentido da verdade, a concepção de Husserl pode ser encarada como uma teoria da correspondência modificada. De acordo com a fórmula tradicional da correspondência, a verdade consiste em uma adequação da mente à coisa; de acordo com Husserl, a correspondência essencial é entre o sentido da intenção e o sentido do preenchimento. ${ }^{32}$

Há, portanto, uma correspondência entre as matérias dos atos unidos na síntese de recobrimento, pois o 'como-o-quê' o objeto é visado é o mesmo na vivência signitiva e na intuitiva (perceptiva). Cobb-Stevens resume a definição husserliana da verdade, em seus momentos distintos, de uma forma bastante sinóptica: primeiramente, expõe-se que "um ato vazio se dirige a um objeto em sua ausência"33, enquanto "um ato intuitivo registra sua presença" ${ }^{34}$. A verdade, então, é definida como "a experiência de uma síntese de identidade na transição de uma visada vazia para uma intuição preenchedora"35 (COBB-STEVENS, 1990, p. 147, tradução nossa). Muito embora nuances importantes sejam obliteradas, o essencial da definição husserliana está presente: há a vivência do recobrimento entre as matérias intencionais dos atos significativo e intuitivo, bem

32 "The primary sense of truth in the Husserlian analysis, and the one from which the others derive, is the first one: truth as the agreement between intention and fulfilment. The second sense is no more than a generalized conception of the first, the universal of which truth in sense 1 is the particular. According to the third sense, a being is a 'true' being when it can be given adequately in intuition; that is, a being for which adequate Evidenz or truth in sense I is ideally possible. Finally, a judgment is true when it is correct (richtig) in the sense that it conforms to (richtet sich nach) true being, to an object which is or can be given adequately [...] Because of the primacy of the first sense of truth. Husserl's conception may be conceived as a modified correspondence theory. According to the traditional correspondence formula, truth consists in an adequation of mind to thing; according to Husserl, the essential correspondence is of meaning-intention to meaning-fulfillment".

33 "An empty act is directed toward an object in its absence".

34 "A fulfilling act registers its presence".

35 "the experience of an identity-synthesis in the transition from empty intending to fulfilling intuition". 
como a identificação de suas qualidades (pois, conforme apontado antes, no contexto de uma experiência de evidência, que tem como correlato a verdade, entra em jogo o caráter posicional dos atos envolvidos). ${ }^{36}$

\subsection{Correspondência e coerência}

Segundo o exposto, a teoria husserliana da verdade aparece como uma espécie de modificação da teoria correspondencial, ou, no mínimo, como uma 'releitura' desta a partir da perspectiva fenomenológica, que leva em conta a descrição das vivências de conhecimento nas quais evidência e verdade se manifestam. No entanto, com base no terceiro significado pontuado por Husserl na $L U V I$, o da verdade como 'ser', como ‘o verdadeiro', Soffer (1991, p. 79ss) afirma que certos traços da definição husserliana sugerem uma fundamentação coerentista para a verdade como correspondência. É sobre essa discussão que iremos manter a atenção a partir de agora.

Soffer nota duas coisas a esse respeito: primeiro, que os dois componentes da relação de adequação são internos à experiência: tanto o conteúdo do ato signitivo, quanto o do ato intuitivo (SOFFER, 1991, p. 79). ${ }^{37}$ Entretanto, suas observações não se detêm sobre este aspecto, mas sobre o segundo: a definição 3 de 'verdade' como 'ser verdadeiro' (true being, para Soffer) indica que o predicado 'verdadeiro' não se aplica somente a juízos, mas, sobretudo, às próprias coisas, aos fenômenos. O 'ser verdadeiro', aqui, seria sinônimo de 'realidade' e oposto a um ser meramente ilusório, uma ficção; por exemplo, um sonho. Assim, "a distinção entre ilusão e realidade, ou entre fenômenos falsos e verdadeiros, é extraída com base em uma coerência exibida pelo fenômeno dentro de um contexto de experiência mais amplo"38 (SOFFER, 1991, p. 80, tradução nossa). O que isso significa? Que uma percepção isolada fornece apenas uma medida reduzida de preenchimento, limitando a demonstração de sua 'realidade’ em contraposição à ilusão. Por outro lado, uma série de percepções conexas

36Um ponto da maior importância não pode deixar de ser citado: Lévinas (1973 apud COBB-STEVENS, 1990, p. 147) afirma que a teoria de Husserl põe por terra qualquer pretensão de correspondência, pois não há nenhum tipo de comparação de algo intra-mental com algo extra-mental; o ato vazio é preenchido por um ato intuitivo. Essa observação não será discutida em detalhe, embora sua importância seja reconhecida ao final de nossa exposição.

37 Observação que remete à crítica de Lévinas. Ver a nota anterior.

38 "The distinction between illusion and reality, or between true and false phenomena, is drawn on the basis of the coherence exhibited by a phenomenon within an overall context of experience". 
de um mesmo objeto pode oferecer um grau mais elevado de preenchimento. Agora, a questão é que uma intenção já fixa os desdobramentos possíveis da experiência que poderão contar como um preenchimento ulterior, ao mesmo tempo em que outros cursos determinados de continuidade da experiência poderiam ser completamente incompatíveis com a doação inicial do objeto (SOFFER, 1991, p. 80). Husserl chega a dizer que, nos casos de discordância da experiência, a percepção inicial "explode", pois há conflito entre o que é visado e o que se dá em evidência - há a ocorrência de uma "determinação diferente daquela que correspondia à doação originária de sentido" (HUSSERL, 2006, p. 308). Ao 'explodir', o objeto é julgado como uma ilusão, ou é substituído por outro objeto. Apesar do nível de abstração empregado nas explicações de Husserl, é fácil compreender do que se trata nessas situações. Imagine-se o exemplo paradigmático da percepção de um cubo. Por aquilo que o próprio cubo é, enquanto um objeto físico, sabe-se que, sendo vistos alguns de seus 'perfis' (um de seus lados, a partir de uma dada perspectiva, por exemplo), os outros permanecem ocultos. Ao mudarmos a perspectiva, girando-o, espera-se que os lados antes ausentes se tornem presentes na intuição. Se a experiência é concordante, na medida em que as perspectivas vão se alterando, o objeto irá se mostrar de diferentes ângulos. O cubo, então, é 'verdadeiro', 'efetivo'. Agora, numa situação em que os dados evidentes se chocam com o curso inicial da experiência, digamos, se, ao girar o cubo, tudo o que percebemos é que ele era apenas uma 'casca' oca, então o objeto inicial é "suprimido, cancelado" (HUSSERL, 2010 , p. 102, grifo do autor). Ou, ainda, se, ao tentar tocar o cubo, nossas mãos passassem através dele, perceber-se-ia que não se tratava de um objeto físico, um corpo com uma determinada massa, mas de uma ilusão (ou até mesmo de um holograma). Cada tipo de objeto tem os desdobramentos possíveis de sua doação prescritos a priori por leis de essência, determinadas pelo eidos da objetidade em questão (HUSSERL, 2006, p. 309). Isso quer dizer que a essência da objetidade pré-determina em que tipo de desenvolvimento concordante da experiência pode haver a vivência de evidência que corrobore seu status de "ser verdadeiro" (HUSSERL, 2006, p. 309; 2010, p. 101-102).

Com base nisso, Soffer conclui:

Em geral, um objeto é verdadeiro quando um conjunto completo de sínteses de preenchimento harmônicas com a intenção inicial pode ser realizado (idealmente), enquanto nenhuma em conflito com ela poderia - ou, 
A noção de verdade na fenomenologia de Husserl: entre correspondência e coerência
Mndo. Allan Josué Vieira

[UFSC]

em outros termos, quando a experiência é coerente consigo mesma. Husserl traça a distinção entre realidade e ilusão fenomenicamente, sobre a base de certa coerência interna da experiência ${ }^{39}$ (SOFFER, 1991, p. 80, tradução nossa). ${ }^{40}$

Assim, o "ser verdadeiro" depende da coerência da experiência, a fim de que possa confirmar seu estatuto como 'efetivo', e não ser tomado como uma ilusão, delírio ou sonho.

Com efeito, o que Soffer (1991, p. 80) chama de "true being" é o que Husserl designa como "efetividade", como "ser efetivo" ou "ser verdadeiro" (2006, p. 304), ou, ainda, como objeto "verdadeiramente existente" (2006, p. 316). O objeto é o 'puro $\mathrm{X}$ ' que se mantém estável em meio à multiplicidade de caracteres noemáticos ${ }^{41}$ que se perfilam no decorrer de uma experiência. No exemplo anterior do cubo, ele é o polo idêntico, o 'mesmo' que se mantém, a despeito das mudanças de perspectiva e daquilo que se perfila para o sujeito (suas 'aparições'). Nas doações evidentes, nas quais a coisa está presente 'ela mesma', esta permanece idêntica durante toda a experiência (idealmente infinita) que se faz dela. É uma síntese de identidade, conceito central para o estabelecimento do objeto 'efetivo', 'verdadeiro'. A objetidade apreendida em doação evidente, numa síntese de identidade concordante, é efetiva. De acordo com Husserl (2006, p. 316, grifo do autor):

39 "In general, an object is a true one when the complete set of syntheses of fulfillment harmonious with the initial intention could (ideally) be carried out, while none of those in conflict with it could be-or, in other terms, when experience is coherent with itself. Husserl draws the distinction between illusion and reality phenomenally, on the basis of a certain internal coherence of experience".

40 Não se pode passar por alto um detalhe digno de nota: Soffer parece deixar de lado o fato de que todos os desdobramentos possíveis de uma experiência são determinados a priori pelo eidos do gênero e da categoria do objeto em questão (HUSSERL, 2006, p. 309). Essas 'puras possibilidades' formam o que Husserl chama de horizonte do objeto (2010, p. 90). Esse horizonte é determinado por leis de essência (HUSSERL, 2010, p. 115). Ora, há que se observar aquilo que Drummond (2007, p. 68) assinala sobre a noção de essência na fenomenologia: trata-se, antes de mais nada, de uma categoria ontológica. Todas as observações de Soffer sobre o 'coerentismo' da experiência parecem ignorar uma tênue, porém, importante distinção, 'dentro' da postura fenomenológica, entre o ontológico e o epistemológico. Esse será o ponto decisivo nas discussões subsequentes.

41 Embora nas $L U$ Husserl ainda não se valha do conceito de noema, é necessário introduzir essa terminologia aqui, uma vez que a interpretação de Soffer remete para além do contexto dessa obra. Logo abaixo estes pontos se tornarão mais claros. 
A todo objeto "verdadeiramente existente" corresponde por princípio (no a priori da generalidade eidética incondicionada) a ideia de uma consciência possível, na qual o próprio objeto é apreensível originariamente e, além disso, em perfeita adequação. Inversamente, se essa possibilidade é garantida, o objeto é eo ipso verdadeiramente existente.

As sínteses envolvidas no estabelecimento do 'ser' ou 'não-ser' dos objetos qua correlatos noemáticos são "intencionalidades de ordem superior" (HUSSERL, 2010, p. 102) e, segundo Smith (2003, p. 160), não são determinadas de acordo com uma simples doação evidente, mas por sínteses de confirmação evidente. Essa distinção remete ao caráter iminentemente temporal de toda experiência e elucida o que Soffer diz com 'coerência' da experiência consigo mesma.

Mantendo-nos no exemplo utilizado por Soffer da percepção 'exterior', o detalhe decisivo é que nenhuma experiência perceptiva é algo instantâneo, que doe seu objeto 'de um único golpe', por assim dizer (SMITH, 2003, p. 162). Cada evidência, na qual o objeto está 'sob nossos olhos', indica uma série de outras evidências possíveis, que validariam o objeto como efetivo (HUSSERL, 2006, p. 309; SMITH, 2003, p. 161). Isso quer dizer que, a cada modo de consciência intuitivo, preenchido, correspondem 'antecipações', momentos ainda vazios, que, na sequência da experiência, podem passar ao preenchimento, e assim sucessivamente. Segundo Husserl,

a cada percepção externa pertence a remissão dos lados propriamente percepcionados do objeto perceptivo para os lados co-visados, não ainda percepcionados, mas apenas antecipados na expectativa e, desde logo, num vazio intuitivo; enquanto lados que virão perceptivamente a partir de agora, trata-se de uma constante protensão, que adquire um novo sentido com cada fase perceptiva (HUSSERL, 2010, p. 90, grifo do autor).

As possibilidades de doação evidente dos aspectos ainda não presentes do objeto formam seu horizonte intencional, que, por sua vez, traz suas potencialidades já pré-determinadas (HUSSERL, 2010, p. 91). A síntese de confirmação 
evidente nada mais é que o curso concordante da experiência, que transcorre de forma harmônica com o horizonte de possibilidades pré-delineado por suas fases primárias; as novas evidências que surgem concordam com as evidências anteriores, fazendo com que, retroativamente, estas últimas sejam corroboradas (SMITH, 2003, p. 162). Assim, uma experiência na qual haja as sínteses de confirmação "nos dá a compreensão do que a realidade é e significa. Que outra base ela poderia ter?"42 (SMITH, 2003, p. 164, grifo do autor, tradução nossa).

A verdade enquanto 'ser', enquanto 'o verdadeiro', 'true being', na leitura de Soffer, seria sinônimo daquilo que Husserl chama, já no período posterior às $L U$, de 'efetividade' (Wirklichkeit). E esta se encontra ancorada na possibilidade de confirmação evidente da experiência: "só podemos estar seguros acerca do ser efetivo através da síntese de confirmação evidente, a qual é auto-doadora da reta ou verdadeira efetividade" (HUSSERL, 2010, p. 104). Agora, devido à “imperfeição da evidência" (HUSSERL, 2010, p. 106) da doação dos objetos exteriores e do mundo, pois estes só aparecem por perfis, e nunca numa síntese que proporcionasse o acesso imediato a todas as perspectivas possíveis, a efetividade do mundo acaba por ser uma 'ideia infinita' de evidências possivelmente confirmantes. Isso significa que:

Objeto efetivo de um mundo e, por maioria de razão, um mundo, ele próprio, são uma ideia referida a infinidades de experiências a unificar de modo concordante - uma ideia correlativa à ideia de uma perfeita evidência de experiência, de uma síntese completa de experiências possíveis (HUSSERL, 2010, p. 107, grifo do autor).

Também em Ideias I a doação adequada de um objeto físico é determinada como um fluxo infinito de aparições contínuas, prescritas eideticamente (por leis de essência), uma "ideia no sentido kantiano" (HUSSERL, 2006, p. 317).

O 'ser verdadeiro', portanto, é fruto de um fluxo temporal de experiências concordantes que se mostram coerentes com aquilo que é determinado eideticamente, portanto, a priori, pelas fases inicias dessa mesma experiência. Sob essa perspectiva, Soffer, pode, então, afirmar que uma espécie de coerência, que aqui se julga ser sui generis, é que dá fundamento para a verdade como correspondência, tal como delineada por Husserl nas $L U$.

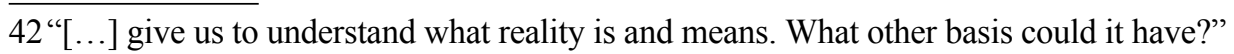


No entanto, o que se pretende questionar é a sinonímia, presumida por Soffer, entre o 'ser no sentido da verdade' da LU VI e o 'ser verdadeiro', 'efetivo', exposto em textos posteriores, como Ideias I e CM. É a passagem brusca de um sentido de 'verdade' a outro que permite associar a teoria correspondencial de Husserl com a coerência interna da experiência. É, efetivamente, tal passagem que está presente como pano de fundo da teoria husserliana das $L U$ ? O 'ser no sentido da verdade' das Investigações remete ao estatuto de efetividade dos objetos dados nas vivências intuitivas?

\section{Verdade como coerência?}

A interpretação de Soffer, que associa o 'ser como verdade', como o 'verdadeiro' (definição 3 de Husserl), com o correlato de uma experiência concordante, o ser enquanto 'efetivo', 'verdadeiramente existente', remete a discussão das $L U$ à fase transcendental da fenomenologia, especialmente à Ideias $I$ e às Meditações cartesianas. Essa conexão, como se viu, conduz Soffer a ver, na teoria husserliana da verdade, sinais de uma teoria coerentista, que, por sua vez, sustenta a ideia da verdade como modificação da concepção correspondencial tradicional. No entanto, pensa-se que há um equívoco nessa interpretação, cujo esclarecimento depende da correta compreensão do contexto dos problemas e conceitos com os quais Husserl está lidando no período das $L U$ e, posteriormente, na fase transcendental da fenomenologia, em Ideias I e CM. Com efeito, o que se pretende mostrar é que a problemática geral permanece a mesma, mas que o sentido de 'ser verdadeiro', de 'verdade', empregado nestas diferentes obras encarna não somente uma mudança no pensamento husserliano, mas, antes, se tratam de termos equívocos, portadores de significados distintos. Se tal confusão na argumentação de Soffer puder ser exposta, a teoria husserliana da verdade poderá se manter como uma modificação da teoria da correspondência tradicional, matizada pelas especificidades do método fenomenológico.

Nas $L U$, a teoria do conhecimento aí pretendida estabelece para si mesma um imperativo metodológico: a "ausência de pressupostos" (HUSSERL, 2012, p. 17), que tem como premissa básica que aquilo que está em jogo nas análises fenomenológicas sobre as vivências de conhecimento deve radicar tão somente nestas e em seus conteúdos, não fazendo qualquer menção sobre a existência das objetidades dadas nesses vividos (HUSSERL, 2012, p. 19-20). A questão sobre a existência de um mundo exterior é de ordem puramente metafísica (HUSSERL, 
2012, p. 18) e, como tal, está excluída da discussão. Com efeito, esse princípio está em ação na $L U V I$, uma vez que o que entra em relação numa vivência cognitiva não é o objeto 'em si' e a expressão significativa (enquanto fenômeno físico), mas as vivências aí envolvidas: os atos 'puros' é que entram na relação de identificação (HUSSERL, 1985, p. 24). A partir daí, as discussões conduzem, inevitavelmente, ao conceito de verdade, uma vez que, já nos Prolegômenos à lógica pura, Husserl acentua a correlação entre conhecimento, evidência e verdade, pois "no saber, possuímos a verdade", e, num sentido rigoroso de saber, faz-se necessária "a evidência, a certeza luminosa de que é, o que reconhecemos, ou de que não é, o que rejeitamos” (HUSSERL, 2005, p. 38, grifo do autor).

Viu-se anteriormente que, na relação de conhecimento, o ato intuitivo é o que traz 'plenitude' a uma intenção vazia. Especificamente, a percepção desempenha aí um papel privilegiado, uma vez que é ela que nos dá "a própria coisa" (HUSSERL, 1985, p. 90). Por sua vez, o que distingue uma vivência intuitiva (no caso, perceptiva) de uma meramente significativa é a apreensão (ou representação apreensiva) de um conteúdo representante específico, isto é, aquele que nos dá o objeto. No caso da percepção, são dados de sensação (HUSSERL, 1985, p. 62). Esse conteúdo representante intuitivo, todavia, só pode ser assim caracterizado se ele apresenta algum grau de semelhança com o objeto visado (HUSSERL, 1985, p. 72, 90). Note-se que, neste momento, toda a empresa husserliana das $L U$ se vê confrontada com uma inconsistência. Pois, uma vez que se estabeleceu como princípio a ideia da ausência de pressupostos, não entrando em linha de conta a existência fática de um mundo exterior e de seus objetos, como é possível pensar a semelhança dos conteúdos representantes com estes mesmos objetos? Afinal, a semelhança é com o que? De acordo com Moura (1989, p. 149),

a investigação da efetividade da relação entre subjetividade e transcendência, que deveria ser uma análise puramente imanente, explicitando o "encontro" entre a consciência e a objetividade unicamente em função da intuitividade interior aos próprios atos intencionais, não pode determinar essa própria intuitividade sem um recurso aos próprios objetos excluídos da investigação pelo princípio da ausência de pressupostos, e sem usar o léxico da semelhança que, ao exigir uma comparação entre o universo representado, destina a fenomenologia às mesmas dificuldades da representação por ideias-quadro anteriormente banida pelo filósofo. 
Assim, a concepção do ato intuitivo como portador de um conteúdo que apresenta por semelhança seu objeto exige "uma comparação impossível" com aquilo que fora deixado em suspenso no início das $L U$ (MOURA, 1989, p. 150). A descrição da relação entre subjetividade e transcendência se torna, nestes termos, irrealizável (MOURA, 1989, p. 151), pois Husserl é acometido dos mesmos problemas das teorias tradicionais do conhecimento, problemas tipicamente cartesianos: o ego que conhece o mundo por meio de seus atos de consciência é um ego psicológico, o que redunda na consequência de que a oposição entre subjetividade e transcendência é uma relação entre um "interior" e um "exterior" (MOURA, 1989, p. 135). Consequentemente, os conceitos decorrentes da relação da síntese de recobrimento entre significação e intuição, como os de verdade e evidência, encontram suas limitações e dificuldades internas. ${ }^{43}$

Com isso, torna-se patente que o problema da efetividade do objeto 'exterior' volta à cena. Mas, o que deve ser destacado é que, nas $L U$, Husserl não fala dessa efetividade, muito menos em relação a uma experiência concordante (na forma de uma confirmação evidente) que transcorra no fluxo de vivências. Apesar do aspecto temporal da percepção e sua consequente mistura de elementos vazios e preenchidos serem citados, apontando para a globalidade do ato como apresentando a "coisa" (HUSSERL, 1985, p. 35), em nenhum momento se faz alusão à efetividade, ao 'ser verdadeiro' dessa coisa. O que vai subrepticiamente apontar para essa efetividade é a noção de semelhança dos conteúdos internos de uma intuição com o objeto visado. Ou seja, o impasse do objeto transcendente se instala no coração da fenomenologia das $L U$. É justamente em relação a esse problema que o conceito de efetividade será desenvolvido a partir de Ideias, ganhando uma versão melhor acabada nas $C M$.

A fase do idealismo transcendental é marcada pela primazia metodológica da epoché e da redução transcendental. Se o universo da investigação fenomenológica se encontra definitivamente demarcado como a consciência pura, a "nova região do ser até agora não delimitada naquilo que lhe é próprio" (HUSSERL, 2006, p. 83, grifo do autor), o objeto não se encontra mais separado dos vividos intencionais. Em última instância, ele será o "puro X", sujeito de seus predicados possíveis, o "idêntico" que permanece em meio à multiplicidade noemática (HUSSERL, 2006, p. 291). Ou seja, o objeto não é nada para além daquilo que é constituído na consciência. Isso, por sua vez, tem como consequência que a

43 Importa notar que o objetivo aqui não é explorar detidamente essas aporias do percurso husserliano. Tão somente se busca tornar claro por quais motivos a interpretação de Soffer (1991) não atenta para os detalhes da argumentação do filósofo e para as nuances da transição entre o período pré-transcendental e o transcendental da fenomenologia e, por isso, não se legitima. No entanto, algumas consequências óbvias serão indicadas ao final do texto. 
subjetividade não possui mais um "exterior" (MOURA, 1989, p. 182); o 'em si' do objeto como uma transcendência, como uma 'pura exterioridade', é eliminado do horizonte investigativo da fenomenologia: o mundo, com todos os seus objetos, ganha sentido e validade a partir da subjetividade transcendental; toda evidência possível tem seu fundamento no ego constituinte (HUSSERL, 2010, p. 73, p. 104-105).

O que isso quer dizer? Nas palavras do próprio Husserl (2006, p. 298), isso significa que "o que quer que possa ser e se chamar mundo e efetividade em geral, tem de ser representado no âmbito da consciência efetiva e possível mediante sentidos ou proposições correspondentes, preenchidos com mais ou menos conteúdo intuitivo". "Is Isso corresponde a dizer que, a despeito da epoché fenomenológica, a diferença entre 'ser verdadeiro' e não-ser não deixa de ser considerada; antes, apresenta-se como um "tema universal da fenomenologia" (HUSSERL, 2010, p. 101). Abordar a temática da realidade das objetidades visadas intencionalmente, segundo Smith (2003, p. 159), traduz a preocupação de Husserl com o fato de que 'realidade' possui um sentido para nós; e, se o que se busca é elucidar esse sentido, é preciso remontar às experiências intencionais nas quais ele é vivido originariamente. Mais que isso: discutir fenomenologicamente o sentido noemático 'efetividade' é a chave para alcançar a fundamentação de "tudo o que se diga de objetos" (HUSSERL, 2006, p. 303), pois os "problemas envolvendo efetividade se encontram em todos os conhecimentos como tais [...] todos têm seus correlatos em 'objetos' que são visados como "efetivamente existentes"' (HUSSERL, 2006, p. 301, grifo do autor).

A partir disso, compreende-se como a elucidação da efetividade é a solução encontrada por Husserl para superar as dificuldades das $L U$. A questão da relação entre subjetividade e transcendência, tornada insolúvel pela abordagem anterior, transforma-se agora na questão da efetividade do objeto qua objeto intencional. Clarificar como a consciência 'atinge' seu objeto equivale a mostrar como o objeto intencional é efetivo, e não meramente visado (MOURA, 1989,

44É preciso ter em mente algumas particularidades do léxico husserliano, especialmente certas mudanças sutis em relação ao período das $L U$. O termo 'sentido', assim como 'proposição', não diz respeito, especificamente, a distinções de ordem linguística ou de expressão conceitual. São termos que se relacionam com todos os vividos da consciência. O sentido é o correlato, pelo lado noemático, daquilo que Husserl chamava, nas $L U$, de matéria do ato, ou seja, o "como-o-quê" o objeto é visado, a determinação específica da visada intencional. Já uma proposição é o sentido mais o caráter tético do noema, isto é, o modo como a objetidade é posta (como um ser efetivo, possível, duvidoso, conjecturado etc.). Ou seja, o caráter tético é o correlato noemático da diferença qualitativa dos atos objetivantes, se eles são posicionais ou não-posicionais $(L U$ $V, \S 38)$. Assim, como Husserl explicita em Ideias $I, \S 135$, nas simples intuições temos um sentido intuitivo e proposições intuitivas. 
p. 243-44). O noema possui uma referência objetiva, dada pelo seu próprio sentido; a tarefa é investigar fenomenologicamente o que significa essa pretensão da consciência de atingir efetivamente essa objetidade, e como tal relação é válida ou não (HUSSERL, 2006, p. 286). Agora, o que precisa ficar claro é que a efetividade em questão não é a dos objetos 'puros e simples', deixados em suspenso pela epoché. O problema todo é relativo ao "sentido objetal": é ao objeto intencional que serão dirigidos os predicados "ser" ou "não-ser" (HUSSERL, 2010, p. 101). Com isso, não se está mais sob a sombra aporética de uma comparação impossível entre os dados da consciência e um objeto que é uma 'exterioridade absoluta', que se contrapõe a um 'interior' da subjetividade.

Para além da síntese na qual o objeto idêntico se confirma como o mesmo, como o "puro X", substrato de seus predicados (HUSSERL, 2006, p. 291), a intuitividade da doação do objeto desempenha um papel central em sua constituição efetiva. O que entra em consideração, então, são modos de consciência nos quais o ato intuitivo é um ato 'doador originário', ou seja, o objeto está ele mesmo presente, como numa percepção direta de algo. O que se tem aí é que "na orientação para o noema, encontramos o caráter da corporeidade (como plenitude originária) fundido ao sentido puro, e o sentido com esse caráter opera então como sustentação para o caráter posicional noemático ou, o que aqui significa o mesmo, para o caráter do ser" (HUSSERL, 2006, p. 304, grifo do autor). No entanto, a intuição não é mais algo que dependa de um conteúdo semelhante ao objeto visado, pois "a intuitividade será diretamente constatável no próprio objeto intencional e não apenas no ato" (MOURA, 1989, p. 245). Toda essa situação é descrita de forma resumida por Husserl também nas CM. Aí, o objeto intencional, o puro 'sentido objetal' tem sua efetividade constatada numa síntese de confirmação evidente (HUSSERL, 2010, p. 104), e isto quer dizer: numa experiência que se desenrola concordantemente no fluxo temporal, uma sucessão de doações evidentes nas quais a própria coisa se dá intuitivamente, dado que a evidência é um "apresentar-se-a-si-próprio", um estar "ele próprio aí, imediata, intuitiva, originalmente dado" (HUSSERL, 2010, p. 102, grifo do autor). No caso paradigmático de uma percepção, essa experiência se traduz, pelo lado dos atos (noese), na presença de dados 'sensíveis', mas estes, por sua vez, não remetem, por semelhança, a nada 'exterior' à consciência: são dados que, pelo lado noemático, apresentam a própria coisa; a intuição é intuição do objeto intencional.

O que importa notar, e este ponto é da maior relevância para a presente discussão, é que somente aqui, na fase transcendental da fenomenologia, é que 
entra em discussão o 'ser verdadeiro' como uma categoria ontológica. ${ }^{45}$ A discussão sobre a efetividade se desenrola sob a égide da redução transcendental e da problemática da relação da subjetividade ao objeto transcendente. Se há uma dimensão na qual é possível falar do 'verdadeiro' como tributário de alguma sorte de coerência, é nessa dimensão ontológica; na delimitação, interior ao plano dos fenômenos puros reduzidos, daquilo que dá a efetividade dos objetos intencionais. Nada disso está presente na definição da evidência e da verdade nas $L U$. Procuremos clarificar melhor as ideias aqui expostas pelo que segue:

1) $\mathrm{O}$ objeto 'verdadeiro', nas $L U$, ainda é exterior à consciência. A relação epistemológica é entre um interior e um exterior; entre uma subjetividade psicológica e uma transcendência absoluta. $\mathrm{O}$ objeto 'verdadeiro' é simplesmente aquele que é dado por meio de perfis, cuja apreensão dos conteúdos, por semelhança, remete a uma mera imagem ou ao objeto em si mesmo. Não se trata do objeto que, de forma imanente ao fluxo temporal da consciência, confirma a si mesmo; não é, nas $L U$, o 'puro $\mathrm{X}$ ' que serve como suporte de suas determinações variantes, que permanece como idêntico no decorrer temporal da experiência concordante, como em Ideias I e CM. Embora Husserl cite as sínteses de identidade de um mesmo objeto (1985, p. 48), em nenhum momento isso conduz a qualquer definição de ordem ontológica. O ‘ser verdadeiro' das $L U$ recebe essa denominação por outros motivos, como se tentará demonstrar a seguir;

2) O 'ser verdadeiro', tal como explicitado por Soffer, é o ser efetivo de Ideias I e CM. Trata-se de um conceito ontológico (que emerge e se justifica fenomenologicamente), antes de mais nada. É a forma pela qual Husserl procura elucidar como o objeto pode ser algo para além dos perfis que se manifestam à consciência. É um 'ser verdadeiro' em sentido ontológico, pois a coerência interna da experiência temporal constitui a efetividade (Wirklichkeit) do objeto; ele confirma a si mesmo como 'verdadeiramente existente'. Se há algo que depende de uma coerência, é a dimensão

$45 \mathrm{O}$ termo ‘ontológico' é usado aqui em relação ao objeto intencional, ou seja, ao polo noemático da relação da consciência com seu objeto, e, especificamente, em relação às determinações que legitimam sua efetividade (Wirklichkeit). Segue-se, nisso, as indicações de Brainard (2002, p. 195-216), para quem a verdade e o conhecimento encontram o fundamento de sua validade no ser (Being), na efetividade, ou seja, dentro da perspectiva da redução transcendental, na confirmação evidente do objeto intencional dado no noema. Obviamente, isso implica em uma distinção, no próprio terreno do ego transcendental puro, entre o epistemológico e o ontológico. 
Mndo. Allan Josué Vieira

[UFSC]

ontológica, tal como pensada a partir da perspectiva transcendental alcançada pela epoché fenomenológica. Nas $L U$, a relação toda é definida pela orientação em direção ao polo epistemológico, isto é, a uma relação de conhecimento na qual uma intenção vazia é preenchida por uma intuição que dá o objeto 'em si mesmo'. Este objeto é 'o ser', 'a verdade', 'o verdadeiro' pelo fato de entrar em uma relação de preenchimento, numa síntese de identidade com uma intenção vazia, verificando um interesse epistêmico implícito na pura visada. ${ }^{46}$ Por isso ele é o 'ser verdadeiro'. Poder-se-ia pensar numa espécie de 'reflexo' da relação epistemológica sobre a dimensão 'ontológica': ao surgir como aquela que preenche a intenção vazia (tanto sua matéria, quanto sua qualidade), a objetidade dada no ato intuitivo recebe em si, como que num movimento de 'retorno' a partir do ato vazio e da síntese de identidade entre ambos, a designação 'ser verdadeiro'; mas, como um 'reflexo' de seu papel na correlação epistemológica, e não pela manutenção de sua identidade em meio ao desdobramento concordante de uma experiência iminentemente temporal, na qual as múltiplas intuições se ordenam como pertencentes ao mesmo ' $X$ ' idêntico. Na relação cognitiva, "o caráter do conhecido é dado ao objeto que aparece na intuição [...] pela circunstância de que a intenção de significação se une ao intuir, à maneira do preenchimento" (HUSSERL, 1985, p. 31). Consequentemente, do mesmo modo: o objeto não é 'simplesmente intuído' na evidência, ele é 'o verdadeiro' pela função que lhe cabe na síntese de preenchimento;

3) Além disso, mesmo que se tratasse do 'ser efetivo' nas $L U$, viu-se que este é distinto da caracterização que recebe no período do idealismo transcendental de Husserl. O 'efetivo', nas $L U$, permanece indefinido, o que Husserl percebe, mais tarde, ser problemático para o projeto fenomenológico (conforme citado acima). Mas, mesmo que se pensasse em um 'efetivo', um 'ser verdadeiro', nas $L U$, que pudesse ser análogo àquele exposto em Ideias $I$ e nas $C M$, ele deveria ser dado sem mais por meio da intuição - no caso, uma percepção, já que é a ela que devemos o fato de estar diante da

46 Na relação de preenchimento, sinônimo de conhecimento (HUSSERL, 1985, p. 33), entra como fator determinante a presença de um interesse epistêmico, no sentido de uma crença que é "reforçada ou confirmada" (HUSSERL, 1985, p. 54), condição que é enfatizada por Bernet (1988, p. 37) 
Mndo. Allan Josué Vieira

[UFSC]

"própria coisa" (HUSSERL, 1985, p. 90) - independentemente dos problemas suscitados pela noção de semelhança como traço distintivo dos atos intuitivos. Ora, se uma percepção deve dar a coisa como 'efetiva', isso ainda não basta para que ela receba o adjetivo 'verdadeira', pois Husserl (1985, p. 94) expressa claramente que, na experiência do preenchimento (consequentemente, da evidência e da verdade), o objeto não é simplesmente vivido como numa percepção adequada. O que, então, seria esse 'plus' que conota o 'ser verdadeiro' da $L U V I$, que o coloca numa categoria distinta daquela da simples doação de si mesmo? Pensa-se que as observações anteriores resolvem essa questão: nada mais é que um 'reflexo' da relação cognitiva sobre o objeto que é dado na intuição. Aqui, nenhuma remissão ao estatuto ontológico daquilo que se dá intuitivamente (ao menos, não diretamente: abstraímos dos problemas postos pela ideia de semelhança entre o conteúdo representante dado na intuição e a coisa transcendente);

4) Uma última, mas pertinente observação: independentemente de se considerar o contexto específico de cada período da filosofia de Husserl, Soffer não estaria invertendo a ordem das coisas? Pois, para ele, a coerência do desdobramento da experiência é que determina o 'ser verdadeiro' da objetidade visada e permite um preenchimento adequado da intenção vazia. Mas, pensa-se, se a experiência que se desdobra concordantemente no fluxo temporal da corrente da consciência for abstrativamente dividida em momentos no tempo, o que se verá é uma multiplicidade de vivências de preenchimento, ou seja, de elementos vazios e com 'plenitude' intuitiva. Para esclarecer mais: considere-se a experiência da decepção da visada, do conflito, e, assim, da quebra da concordância interna da experiência em sua totalidade. O que ocasiona essa ruptura? Tão somente um não preenchimento de uma visada vazia 'antecipativa' daquilo que 'deveria' se dar intuitivamente, dada a objetidade em questão. Logo, o que sustenta o quê? Pensa-se que a relação de preenchimento tem precedência relativamente ao decurso harmônico da experiência dentro dessa intrincada estrutura. ${ }^{47}$

47É-se consciente de que deve ser considerado o fato de que a experiência do mundo como uma totalidade é anterior às experiências particulares de seus objetos. O mundo já demanda uma experiência concordante a fim de que se estabeleça sua efetividade. No entanto, tal questão já remeteria para um exercício de fenomenologia genética, isto é, que considere a constituição das objetidades em sua 'história' na vida do ego, algo que está para muito além dos problemas 


\title{
3.1. A verdade como 'ser' na sexta investigação lógica
}

A fim de dar enfoque final à discussão, especialmente à tese defendida de que há um 'reflexo' da síntese de identidade, que caracteriza a evidência, sobre $\mathrm{o}$ ato intuitivo e o objeto aí representado, atente-se para uma rápida análise das palavras do próprio Husserl:

\begin{abstract}
Ademais, por parte do ato que traz plenitude, vivemos na evidência o objeto dado à maneira do que é visado: ele é a própria plenitude. Também ele pode ser designado como o ser, a verdade, o verdadeiro [das Sein, die Wahrheit, das Wahre], ${ }^{48}$ precisamente na medida em que é vivido aqui não como era vivido na mera percepção adequada, mas como plenitude ideal para uma intenção, como verificante; ou como a plenitude ideal da essência cognitiva específica da intenção (HUSSERL, 1985, p. 94, grifo nosso, tradução modificada).
\end{abstract}

Indo além do fato já indicado de que o objeto intuído não é vivido como numa simples percepção adequada, considere-se a alusão a este mesmo objeto como 'verificante', ou como 'plenitude ideal da essência cognitiva específica da intenção': tem-se aqui, pensa-se, indicações precisas sobre a natureza da relação em questão.

A verificação é uma síntese de cunho particular, que se refere a atos posicionais (tanto o que visa de maneira vazia, quanto o que dá a plenitude) e à relação destes com o preenchimento (o recobrimento entre ambos), que também tem o caráter da posicionalidade (HUSSERL, 1985, p. 93). É relativamente ao caso específico da verificação que Husserl define a evidência na LU VI: "Falamos em evidência, no sentido lato, sempre que uma intenção posicionante (sobretudo, uma afirmação) é confirmada por uma percepção correspondente e perfeitamente adequada, mesmo que se trate de uma síntese adequada de percepções singulares conexas"49 (HUSSERL, 1985, p. 93). E, logo adiante, o filósofo completa:

aqui tratados. No entanto, remetendo para essa 'história' da constituição da vida intencional do ego, o jogo entre visadas vazias e preenchidas não é algo de irredutível, de originário, para usar um termo caro a Husserl?

48Cf. HUSSERL, 1984, p. 652.

49Embora Husserl não desenvolva em detalhe os caracteres temporais da experiência perceptiva nas $L U$, parece bastante claro que a 'síntese adequada de percepções singulares conexas' não 
A própria evidência, dizíamos, é o ato daquela síntese de recobrimento, a mais perfeita de todas. Como toda identificação, ela é um ato objetivante. Seu correlato objetivo é chamado de ser no sentido da verdade ou também de verdade [Sein im Sinne der Wahrheit oder auch Wahrheit $]^{50}$ (HUSSERL, 1985, p. 93, grifo do autor).

Ou seja, a verdade e o ser no sentido da verdade, aqui, são o correlato do recobrimento entre um ato que visa de forma vazia (significativamente) e outro que traz a plenitude (em medida maior ou menor) do objeto visado. Não se trata do desdobramento temporal de uma percepção concordante com a essência objetal envolvida.

Além disso, o objeto aparece como o que dá a 'plenitude ideal da essência cognitiva da intenção'. O que é a essência cognitiva? Trata-se da qualidade, da matéria e do conteúdo representante intuitivo, sendo que este último falta para a intenção ainda vazia. Em suma, é o conteúdo relevante para a função cognitiva (HUSSERL, 1985, p. 75). O 'ser', o 'verdadeiro', no sentido da terceira definição, é o objeto apresentado, porque ele recobre, além da matéria (o "como-o-quê" do objeto visado) do ato vazio, também sua qualidade, seu caráter de belief, de 'ter-por-verdadeira' a objetidade visada. Uma vez que ele serve como verificante para a intenção vazia, ele é o 'ser no sentido da verdade'. Mesmo que se permita um salto entre as $L U$ (onde o caráter de efetividade do objeto permanece indefinido e problemático) e o período de Ideias I e das $C M$ (no qual há a demarcação explícita do status ontológico do correlato intencional), o 'ser verdadeiro' da $L U$ VI não é a simples efetividade do objeto que confirma a si mesmo segundo um desenvolvimento coerente da experiência. O objeto é 'recoberto', por assim dizer, por uma segunda camada de sentido, conferida pela confirmação do interesse cognitivo presente no ato intencionante, isto é, pela confirmação/verificação da qualidade do ato significativo. ${ }^{51}$ Tal interpretação

é nada mais que a experiência temporal concordante que, em Ideias $I$ e $C M$, dá a afetividade do objeto. Se uma leitura anacrônica for permitida, então é essa efetividade que, confirmando-se no fluxo da experiência, servirá como verificante para o ato intencionante vazio, o que concorda com a visão de Soffer (1991, p. 91ss). Contudo, a coerência, interpretada a partir dessa 'ponte' entre o período pré-transcendental e o transcendental da fenomenologia, é interna ao ato que dá a plenitude, à percepção. Por sua vez, a relação desta última com a intenção signitiva vazia ainda é de adequação.

50 Cf. HUSSERL, 1984, p. 651.

51 Husserl (1984, p. 652) adjetiva o objeto dado na intuição como "wahrmachender", que poderia ser vertido como 'produtor de verdade'. Findlay, na tradução para o inglês, expressa a passagem em questão dizendo que o objeto é vivido "como aquilo que torna uma intenção 
concorda com a característica imputada por Husserl às vivências cognitivas, tais como as que são abordadas em primeiro plano na $L U V I$, que é a de remeter sempre a uma crença que é reforçada ou confirmada (HUSSERL, 1985, p. 54). Com efeito, isso também se coaduna com a interpretação de Sokolowski, ${ }^{52}$ para quem a síntese de identidade, envolvendo três atos distintos, é um ato diferente de uma mera percepção sensível de um objeto (SOKOLOWSKI, 1974, p. 29). É a partir dessa estrutura tripartite que se pode falar em conhecimento, e consequentemente, em verdade em sentido epistemológico.

Por fim, quando Husserl busca definir as relações entre ser e verdade ( $L U$ $V I, \S 39)$, ele diz que:

O ser, no sentido da verdade, teria que ser então determinado, segundo [as definições] 1 e 3 , como a identidade do objeto ao mesmo tempo visado e dado na adequação, ou ainda [...] como tudo aquilo que é adequadamente perceptível tendo uma relação indeterminada a uma intenção qualquer que, por seu intermédio, poderá tornar-se verdadeira (adequadamente preenchida) (HUSSERL, 1985, p. 96, grifo nosso).

Parece claro, por essa definição, que o 'ser no sentido da verdade' é essencialmente determinado por uma relação cognitiva, nada sendo pressuposto acerca de sua efetividade, muito menos relativamente a um processo concordante de confirmação evidente que se desdobre temporalmente (que caracterizaria, para Soffer, os aspectos coerentistas implícitos na teoria husserliana). Aquilo que primariamente é portador dos predicados 'verdadeiro/falso' é a intenção que visa o objeto. A partir daí, com o resultado que a evidência tem sobre o ato que, por sua causa, torna-se 'verdadeiro', 'correto', é que o objeto pode ser chamado de 'verdadeiro'. O que resta, portanto, é tão somente a versão que Husserl oferece da adaequatio: a verdade, em qualquer das acepções assinaladas na $L U V I$, permanece uma correspondência entre o visado e o dado em evidência.

verdadeira" ("as that which makes an intention true"). Isto significa: o objeto verificante dado na intuição é o que torna a intenção anteriormente vazia verdadeira. Por isso é o 'ser no sentido da verdade'. Cf. HUSSERL, 2001, p. 264.

52 Cf. acima, seção 2.1 . 


\section{Considerações finais}

Como nota final ao texto, ainda se fazem pertinentes algumas observações. Tem-se consciência do limite das investigações expostas, dado o escopo pretendido para o trabalho. Procurou-se manter as discussões no âmbito do que Husserl apresenta nas $L U$, estendendo algumas análises até o período posterior, especificamente Ideias I e CM. Esse avanço foi estimulado pela interpretação de Soffer (1991) e pela posterior discussão das posições apresentadas por esse autor. No entanto, uma análise exaustiva das mudanças pelas quais passou a teoria husserliana da verdade, estreitamente ligada à noção de evidência, seria algo impraticável nesse momento. A complexidade da temática e o consequente nível de profundidade exigido por uma discussão consequente, 'responsável por si mesma', utilizando uma linguagem husserliana do período tardio, representam tarefas que estão para muito além do que aqui se propôs. No entanto, algumas breves indicações podem ser hauridas.

Ao longo das discussões empreendidas, pôde-se notar o modo pelo qual Husserl procurou caracterizar, de acordo com as particularidades da fenomenologia, a verdade como uma adaequatio rei et intellectus. A correspondência se torna uma relação de preenchimento entre intenções vazias e intuitivas, tornando correlatas as noções de verdade e evidência. Com a apresentação destes conceitos, tal como realizada, sobretudo, na $L U V I$, surgiu a ideia de que a teoria husserliana, enquanto uma releitura da concepção correspondencial da verdade, teria em sua base uma espécie de coerentismo. Tal interpretação é assinalada por Soffer (1991), para quem o 'ser verdadeiro' das $L U$ é aquilo que, mais tarde, em Ideias $I$ e $C M$, será identificado como o 'ser efetivo', 'verdadeiramente existente'.

Procurou-se mostrar que o significado de 'ser verdadeiro', na LU VI, não coloca em jogo a estrutura conceitual apontada por Soffer (1991, p. 79ss). O ser na condição de efetividade (Wirklichkeit) não é o que aí está implicado (ao menos, não diretamente, e muito menos nos termos segundo os quais este tema será tratado posteriormente na filosofia de Husserl). Mesmo que se admita o salto cronológico e conceitual operado por Soffer, o 'ser verdadeiro' que depende de uma experiência coerente consigo mesma (de acordo com o eidos da objetidade em questão) é algo de ordem 'ontológica', e não epistemológica, como nas $L U$. Se há uma remissão da adaequatio a fatores coerentistas, é somente no que se poderia chamar de uma 'relação de $2^{\circ}$ grau', pois a experiência cognitiva na qual se desenrolam as vivências da evidência e de seu correlato objetal, a verdade, permanece sendo entre atos intencionais vazios e preenchidos, ou seja, de acordo com o modo pelo qual Husserl reinterpreta a noção de 
verdade como correspondência. No entanto, tratar a questão a partir desse prisma implica assumir uma distinção, dentro da esfera transcendental alcançada após a epoché, entre dimensões marcadamente epistemológicas e ontológicas. Esta, com efeito, é a posição defendida por Brainard (2002, p. 195-96, p. 209, p. 212-13), para quem, mesmo após a redução, o ser tem prioridade sobre o conhecimento; ele funda todo o pensar, consequentemente, toda possibilidade de verdade: "A razão, não menos que a verdade, necessariamente tem seu critério último no ser"53 (BRAINARD, 2002, p. 212, tradução nossa). O polo noemático da relação intencional (isto é, o visado enquanto tal) responde pela esfera ontológica imanente à vida da consciência do ego transcendental.

Essa distinção é algo que o próprio Husserl se sentiu compelido a realizar? Com base nas discussões anteriores, pensa-se que sim: é o modo pelo qual se tornou possível superar as aporias que as $L U$ encontraram em seu ponto de chegada, quais sejam, os problemas tornados insolúveis, pela própria postura adotada, relativos ao modo pelo qual seria possível à subjetividade alcançar um objeto que lhe é transcendente. Essa distinção, entretanto, origina novas questões: como pensar essa diferenciação, uma vez que ambas as esferas decorrem de uma mesma espécie de vivência, a da evidência e da confirmação evidente? Com efeito, atentando para as $C M$, onde o tema é tratado brevemente, mas de forma paradigmática, a experiência na qual algo se dá em evidência originária, e, especialmente, numa síntese evidente de confirmação, acaba por projetar sobre o sentido objetal os predicados 'ser/não-ser', pelo lado noemático, e 'verdadeiro/ falso', pelo lado noético (HUSSERL, 2010, p. 101). Aqui, alcança-se um ponto crucial, pois está em jogo uma questão relativa a algo assinalado brevemente, mas não desenvolvido, por Soffer (1991, p. 79) e também por Bernet (1988, p. $39)^{54}$, que, por sua vez, coaduna-se com as críticas de Lévinas (apud COBB-STEVENS, 1990, p. 147): as condições de verdade (correção) de uma intenção vazia são 'interiores' ao ego, o que aponta para a coerência da vida intencional. Aqui, efetivamente, o problema de um suposto coerentismo na filosofia de Husserl ganha sua devida relevância, pois as sínteses constitutivas pelas quais algo se confirma como 'realidade', como 'ser verdadeiro', nada mais são que operações do próprio ego transcendental, assim como os atos carentes de preenchimento.

53 "Reason no less than truth necessarily has its ultimate standard in Being".

54Embora a discussão de Bernet aborde o tema das intuições categoriais e das 'leis do pensamento próprio e impróprio’ ( $L U V I$, cap. 6 e 8), não abarcadas aqui, o essencial de seus comentários tem ressonância nas questões indicadas, pois a verdade permanece somente como a concordância entre o conteúdo (intencional e real) dos atos intencionais, o que, então, aponta para "uma concepção de verdade orientada primariamente para a coerência da vida cognitiva" (BERNET, 1988, p. 39, tradução nossa) ("[...] a concept of truth oriented primarily toward the coherence of cognitive life"). 
Nesse ponto, acredita-se que se toca num problema fundamental para a fenomenologia husserliana: a natureza da própria redução fenomenológica. Com efeito, o problema inicial da fenomenologia é o do conhecimento; é a dimensão epistemológica que tem prerrogativa sobre todas as outras, pois as condições de conhecimento devem ser asseguradas antes de qualquer investigação metafísica, o que motiva a epoché e a redução (MENSCH, 1988, p. 5). A teoria do conhecimento precede a metafísica e qualquer das ciências naturais (HUSSERL, 2005, p. 226; 2012, p. 19); a fenomenologia, antes de mais nada, deve ser caracterizada como uma "teoria transcendental do conhecimento" (HUSSERL, 2010, p. 124). Desse modo, somos conduzidos à hipótese de que todo o sentido objetal possível, inclusive o da efetividade, é delimitado de saída como algo de ordem puramente epistemológica. Não se está diante daquilo que Ricoeur designa como uma "decisão não tematizada e que se pode com razão denominar "metafísica", que acaba por definir, de antemão, que "a questão ontológica é a questão epistemológica"? (RICOEUR, 2009, p. 183-84). ${ }^{55}$ Se, antes da redução fenomenológica, já está determinado que tudo aquilo que a elucidação fenomenológica visa descrever é da ordem do conhecimento, qual o status da distinção epistêmico-ontológica que é imanente ao domínio da investigação transcendental?

Se a fenomenologia é um tipo de filosofar no qual o ontológico acaba por se dissolver no epistemológico, devido à natureza da redução fenomenológica e da preocupação com as objetidades apenas qua correlato noemático da consciência, ainda é possível pensar a empresa filosófica de Husserl como pretensão de um fundacionismo radical, e não como uma simples coerência interna dos atos do próprio cogito a ser elucidado pela reflexão? Ou essa forma de encarar o modus operandi da fenomenologia é algo sobrecarregado com preconceitos originados na tradição filosófica anterior, sendo um ponto de vista estreito, que não apreende em toda a sua envergadura sua verdadeira natureza? Pois questões que estivessem para lá do fenomênico seriam, para Husserl, um total contrassenso, ou, no mínimo, não passíveis de resposta (SOFFER, 1991, p. 81). Parece-nos que são problemas dignos de atenção, uma vez que aí se pode estar jogando a sorte da própria fenomenologia relativamente à sua relevância (ou não) como um modo específico de se fazer filosofia. Trata-se de questões que podem indicar se a fenomenologia merece, ainda hoje, algo mais que um honroso lugar na História da Filosofia, e isto significa pensar se o projeto idealizado por Husserl ainda é capaz de suscitar perguntas pertinentes ao labor filosófico atual, e mesmo se pode indicar, paralelamente, maneiras através das quais se possa respondê-las.

55 Ricoeur, aqui, faz eco às objeções levantadas por Ingarden em suas notas críticas ao texto das CM. Cf. HUSSERL, 2010, p. 208-9. 
BERNET, R. Perception, Categorial Intuition and Truth in Husserl's Sixth "Logical Investigation”. In: SALLIS, J. C.; MONETA, G.; TAMINIAUX, J. (Ed.). The collegium phaenomenologicum: the first ten years. Dordrecht: Kluwer Academic Publishers, 1988, p. 33-45. (Phaenomenologica 105).

BRAINARD, M. Belief and its Neutralization: Husserl's System of Phenomenology in Ideas I. Albany, NY: State University of New York Press, 2002.

COBB-STEVENS, R. Husserl and Analytic Philosophy. Dordrecht: Kluwer Academic Publishers, 1990. (Phaenomenologica 116).

DRUMMOND, J. J. Historical Dictionary of Husserl's Philosophy. Lanham, Maryland: Rowman \& Littlefield, 2007.

HUSSERL, E. Logische Untersuchungen. Dordrecht: Kluwer Academic Publishers, 1984. (Husserliana XIX).

Investigações lógicas: sexta investigação: elementos de uma elucidação fenomenológica do conhecimento. Tradução de Z. Loparic. 2. ed. São Paulo: Abril Cultural, 1985. (Os pensadores).

.Logical Investigations. Volume 2. Translated by J. N. Findlay. London: Routledge, 2001.

.Investigações lógicas. Primeiro volume: Prolegômenos à lógica pura. Tradução de D. Ferrer. Lisboa: Centro de Filosofia da Universidade de Lisboa, 2005.

Ideias para uma fenomenologia pura e para uma filosofia fenomenológica. Tradução de M. Suzuki. Aparecida, SP: Ideias \& Letras, 2006.

Meditações cartesianas e Conferências de
Paris. Tradução de P. M. S. Alves. Lisboa: Centro de Filosofia da Universidade de Lisboa, 2010.

.Investigações lógicas: segundo volume, parte I: investigações para a fenomenologia e a teoria do conhecimento. Tradução de P. M. S. Alves e C. A. Morujão. Rio de Janeiro: Forense Universitária, 2012.

LYNCH, M. P. Truth. In: BERNECKER, S.; PRITCHARD, D. (Ed.). The Routledge Companion to Epistemology. New York: Routledge, 2011, p. 3-13. (Routledge Philosophy Companions).

MENSCH, J. R. Intersubjectivity and Transcendental Idealism. Albany, NY: State University of New York Press, 1988.

MORAN, D.; COHEN, J. The Husserl Dictionary. London: Continuum International Publishing Group, 2012. (Continuum Philosophy Dictionaries).

MOURA, C. A. R. de. Crítica da razão na fenomenologia. São Paulo: Nova Stella, Editora da Universidade de São Paulo,1989.

RICOEUR, P. Na escola da fenomenologia. Tradução de E. F. Alves. Petrópolis, RJ: Vozes, 2009.

SMITH, A. D. Routledge Philosophy Guidebook to Husserl and the Cartesian Meditations. New York: Routledge, 2003. (Routledge Philosophy Guidebooks).

SMITH, D. W. Husserl. Oxon: Routledge, 2007. (Routledge Philosophers).

SOFFER, G. Husserl and the Question of Relativism. Dordrecht: Kluwer Academic Publishers, 1991. (Phaenomenologica 122). 
SOKOLOWSKI, R. Husserlian Meditations: How Words Present Things. Evanston: Northwestern University Press, 1974. 